\title{
EUROPEAN INVESTMENT BANK AS A SUPPORTER OF EUROPEAN PPPS
}

\author{
KRYSTYNA BRZOZOWSKA \\ University of Szczecin, Faculty of Management and Economics of Services, POLAND \\ e-mail: krystyna.brzozowska@wzieu.pl
}

\author{
\begin{tabular}{l|l} 
RECEIVED & 18 January 2018
\end{tabular} \\ \begin{tabular}{l|l} 
ACCEPTED & 2September 2018
\end{tabular} \\ JEL \\ CLASSIFICATION G21, H44, H54
}

KEYWORDS European Investment Bank, public-private partnership, loan, infrastructure project

ABSTRACT The aim of a paper is to examine EIB activities in financing, advising and promotion of PPPs in EU member countries. Research is based on data gained from published by EIB materials and statistics. PPPs are much more complicated in legal, social, political, economical sides than projects conducted traditionally by public sector. Moreover high level of capital intensity of infrastructure assets is a stumbling block to gather the whole amounts to cover investments, mainly in form of loans. Banks become one of the main partners, and at the same time decision makers in PPP projects. A high level of risks in PPP projects combined with high level of capital intensity eliminates small, local banks leaving in the field big commercial banks and multilateral institutions, like as World Bank Group, Asian Development Bank, or in Europe European Bank of Reconstruction and Development and European Investment Bank (EIB). EIB is both a bank and a public institution. Together with loans EIB also offers advisory and technical assistance which can help projects to maximise value for money. As a unique financial institution EIB plays a catalytic role in promoting sound and important projects towards EU policy. The main task of EIB is to contribute towards the integration, balanced development and economic and social cohesion of EU Member States. EIB plays very crucial role in PPP development in EU, specially in countries with not very sophisticated financial markets. It seems that EIB is the biggest supplier of funds to finance PPP in European market.

\section{Introduction}

Public-private partnership (PPP) has been known for centuries, but nowadays there is noticed a renaissance of such activities. The main engine of PPPs development is a scarcity of funds on state budget levels parallel to still increasing investment needs in infrastructure as a result of forceful technical and technological progress all over the world and increase of people expectations of adequate quality of provided public services. 
PPPs are much more complicated in legal, social, political, economical sides than projects conducted traditionally by public sector. Moreover high level of capital intensity of infrastructure assets is a stumbling block to gather the whole amounts to cover investments, mainly in form of loans. Banks become one of the main partners, and at the same time decision makers in PPP projects. A high level of risks in PPP projects combined with high level of capital intensity eliminates small, local banks leaving in the field big commercial banks and multilateral institutions, like as World Bank Group, Asian Development Bank, or in Europe European Bank of Reconstruction and Development and European Investment Bank (EIB).

The aim of a paper is to examine EIB activities in financing, advising and promotion of PPPs in EU member countries. Research is based on secondary data gained from published by EIB materials and statistics.

\section{Overview of ElB activity}

European Investment Bank (EIB) was established in 1958 in force of Treaty of Rome and the same it is the world's oldest regional multilateral development bank and the largest lending institution by volume (Xianbai, 2017, p. 263). It has a mandate to operate as a European Union bank, supporting investments within EU and beyond in the interest of the 28 nations block.

As a unique financial institution EIB plays a catalytic role in promoting sound and important projects towards EU policy. The main task of EIB is to contribute towards the integration, balanced development and economic and social cohesion of EU Member States. The Bank reports to its Board of Governors, made up of a Government Minister from each Member State, usually the Minister of Finance.

At the beginning of its activity EIB financed projects from obligatory payments of Member States (Honohan, 1995, p. 318). This situation has been changing for years. At present EIB finances itself by borrowing on the international capital markets rather than drawing on the budgetary resources of Member States. The Bank raises substantial volumes of funds on the capital markets - about EUR 55 billion annually in recent years - which it lends on favourable and long- term conditions to large - scale capital projects (Investment, 2018). It operates in keeping with strict banking practice and in close collaboration with the wider banking community, both when borrowing on the capital markets and when financing projects (Tujinman, 2009).

EIB is both a bank and a public institution (Investment, 2018). As a bank EIB gains money from international capital markets with its AAA credit rating note. As a public institution - as a representative of 28 member countries - destines collected funds to finance investment projects with sustainable and growth potentials around four priority areas:

- strategic infrastructure,

- small and medium entities,

- climate action,

- innovation and skills.

All the projects in which EIB has been involved must be bankable and comply with strict economic, technical, environmental and social standards. EIB acts as non- profit institution granting loans and guarantees on investment projects (Table 1). 
Table 1. Major products and services of EIB

\begin{tabular}{ll}
\hline & Array of services and products provided by EIB \\
\hline Project loans & Sustainable energy \\
Inter-mediated loans & Infrastructure project advise \\
Structured finance & Urban development \\
Guarantees & Transport infrastructure \\
Project bonds & Public-private partnership \\
Venture capital & Risk sharing \\
Micro finance & Green- tech demonstration \\
\hline
\end{tabular}

Source: World (2015).

Together with loans EIB also offers advisory and technical assistance which can help projects to maximise value for money. Interest rates are equal for every borrower, despite of type of project, investment country and sector. Rates are based on EIB's own marginal cost of funds plus small spread (up to $2 \%$ ) to cover administrative costs and withdrawals for reserve funds. The typical EIB loan is long term with maturity of between 7 and 12 years for industrial borrowers and up to 20 years for infrastructural projects and covers up to $50 \%$ investment costs (in infrastructure projects commonly up to $35 \%$ ). EIB demands a submission of bank guarantees on construction risks and an acceptance of a project by investment side country. It should be underlined that EIB does not involve into capital market projects (Finanse, 2006).

The EIB does not pay dividends to its shareholders (Member States). The bank, despite of its non- profit nature, is a profit- making institution (Brzozowska, 2014). Profits have been retained over the years helping to build the capitals and reserves (Table 2).

Table 2. EIB own funds composition 2015-2016 (EUR million)

\begin{tabular}{lrr}
\hline \multicolumn{1}{c}{ Composition } & 2015 & 2016 \\
\hline Capital & 21,699 & 21,699 \\
Reserves & 38,867 & 41,624 \\
Profits from financial year & 2,757 & 2,857 \\
\hline
\end{tabular}

Source: Financial (2016-2017).

Last years the profits were around EUR 3 billion (2015 - EUR 2757 million, 2016 - EUR 2857 million), that means level of 0.6 per cent of granted loans that time.

\section{PPP development in Europe}

The term Public- Private Partnership (PPP) has been commonly used since the early 90., however there is no any unique European model of a PPP (The EIB's, 2004). Simply, a public-private partnership means an arrangement between a public authority and a private partner designed to deliver a public infrastructure project and service under a long-term contract. Under this contract, the private partner bears significant risks and management responsibilities. The public authority makes performance-based payments to the private partner for the provision of the service (e.g. for the availability of a road) or grants the private partner a right to generate revenues from the 
provision of the service (e.g. tolls from users of a bridge). The core objective for the public sector of PPP projects is to input private sector skills in supporting or improving public sector services. When properly prepared, PPP projects can provide significant benefits to the public sector as well as to the project users (PPPs, 2018). Such projects may engage private sector on new assets, or upgrading of existing ones. Typical examples of PPP projects are roads, airports, railways, bridges, tunnels, water treatment plants, schools, hospitals, government offices, sport facilities, or prisons.

PPPs, combining private and public sector resources, play an important and still increasing role in infrastructure development in Europe (Figure 1).

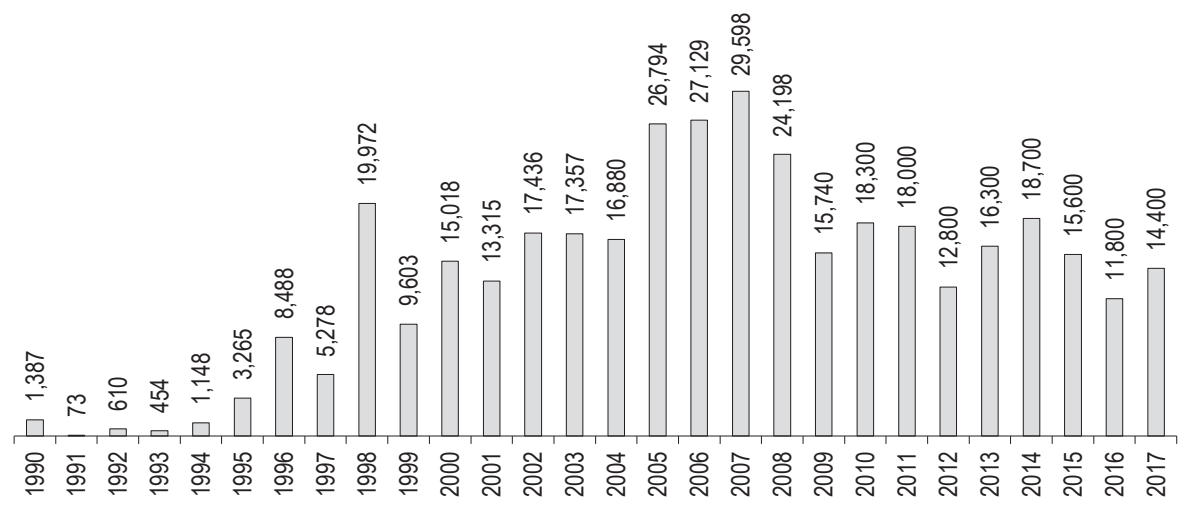

Figure 1. Value of PPP projects in EU (euro million)

Source: by own based on Market (2010-2017).

In past PPPs in Europe have had periods of decreasing and periods of increasing. Till 1998 a progress in PPPs projects was rather poor (in project values), then a sharp almost three- fold increase has been noticed. The best years of PPPs activity in European project market were 2005-2007, then as a result of financial crunch this activity was fallen to the value of 2002-2004. It should be underlined that the last years were not very fruitful for PPPs projects.

Geographically the PPP market has been concentrated around the United Kingdom as a first mover and absolute leader in PPPs applications in various sectors (the UK PPP market represents around $25 \%$ of the overall EU PPP market). After a leader Portugal, Spain, Greece, the Netherlands, Denmark followed, and France, Italy and Germany have joined as an important players lately.

Most countries commenced PPPs in transport sector (roads and motorways, tunnels and bridges, airports) which is still the main sector of PPP applications, but a share of water treatment, power transmission and distribution, urban development, and social infrastructure (mainly in health and education) becomes more and more notable.

\section{EIB involvement into PPPs financing}

The EIB's involvement into PPPs covers all types of transactions like as design-build-finance- operate, build-finance-maintain, design-finance-operate, build-operate-transfer, concession arrangements, provision 
of public services and a risk sharing between public and private sector regardless of the type of financing provided by EIB (project finance, sovereign lending). The loan portfolio contains amounts of loan commitments on date of signature loan agreements signed for big PPP projects without small PPP projects and investments into equity funds (Figure 2).

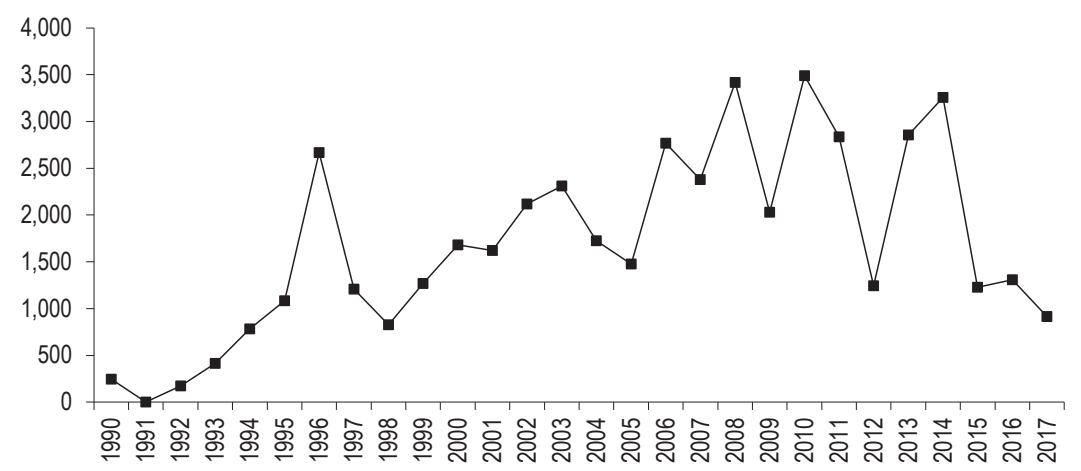

Figure 2. Amounts of ElB's financial support (loans) to PPPs in EU countries (EUR million)

Source: by own based on PPPs (2018), pp. 1-21.

Almost 30 years of EBI involvement into PPP projects has been distinguished by very variable curve. Only at the beginning till 1996 the progress in amounts of granted by EIB loans grew year to year, and later the situation has been changing dramatically up- down each year.

Table 3. The biggest engagements if EIB in PPP projects in Europe

\begin{tabular}{llccc}
\hline \multicolumn{1}{c}{ Country } & \multicolumn{1}{c}{ PPP Project } & $\begin{array}{c}\text { Amount of EIB loans } \\
\text { (EUR million) }\end{array}$ & Sector & Year \\
\hline Denmark & Great Belt Link 3 & 784 & transport & 1994 \\
Denmark & Great Belt Link 4 & 1,069 & transport & 1996 \\
Greece & New Athens International Airport & 999 & transport & 1996 \\
Denmark & Oerosund Link 2 & 1,088 & transport & 1997 \\
United Kingdom & London Underground & 1,349 & transport & 2002 \\
Poland & A1 Motorway: Nowe Marzy - Toruń & 575 & transport & 2008 \\
Sweden & New Karolinska University Hospital & 699 & transport & 2010 \\
France & LGV Sud Europe Atlantique & 1,186 & transport & 2011 \\
France & LGV Bretagne -Pays de la Loire & 638 & transport & 2011 \\
Italy & Autostrada BreBeMi & 700 & transport & 2013 \\
Italy & Milan Eastern Ring Road & 700 & transport & 2014 \\
\hline
\end{tabular}

Source: PPPs (2018), pp. 1-21.

Regarding to amounts of granted by EIB loans to PPPs its share in values of PPP projects also changed from more than $19 \%$ in 2010 , through $17,5 \%$ in 2013 to $6,37 \%$ in 2017. Details are contained in Figure 3. 


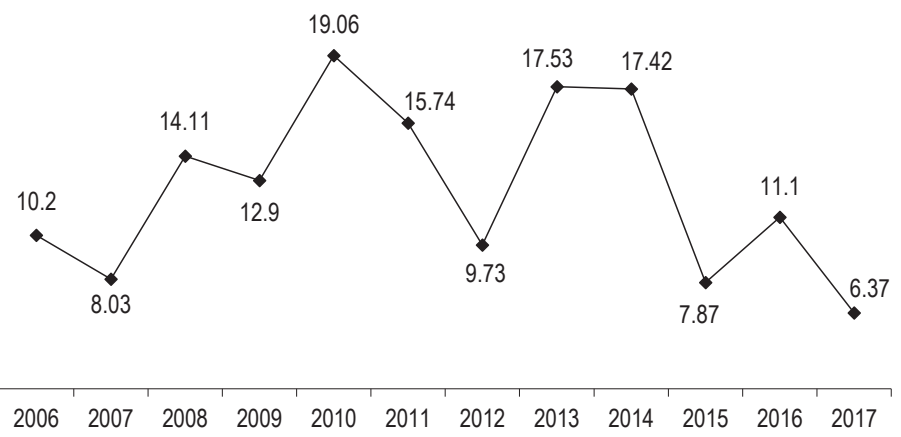

Figure 3. A share of EIB loans for PPP to PPP value (\%)

Source: by own based on Market (2007-2018), PPPs (2018), pp. 1-12.

Like it was mentioned transport has been the main sector covered by PPP projects. Despite of relatively big value of transport projects differences among transport and other sectors are enormous (Figure 4). The other sectors co-financed by ElB's loans are: health, education, water treatment, waste management. The careful attention on transport projects is compatible with bank strategy setting its priorities mainly in transport investments.

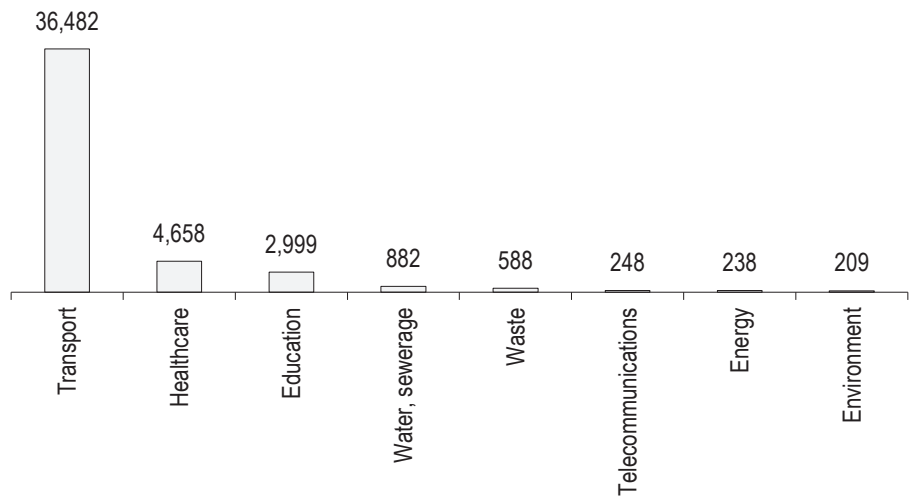

Figure 4. Sectoral PPPs financed by EIB's loans I total (EUR million)

Source: by own based on PPPs (2018), pp. 1-21.

Given EIB engagement in PPP projects by countries (Figure 5) in total (1990-2017) the biggest beneficiaries are projects located in: Portugal, Denmark, Poland, France, next group is: Greece, Germany, Italy and the Netherlands.

In sum, EIB plays very crucial role in PPP development in EU, specially in countries with not very sophisticated financial markets. It seems that EIB is the biggest supplier of funds to finance PPP. However activity of EIB in PPPs development is difficult to overestimate there is not very important in numbers or share. A contribution of loans for PPP is in frames of 0,2 to $1,2 \%$ of whole EIB loan portfolio (Figure 6). 


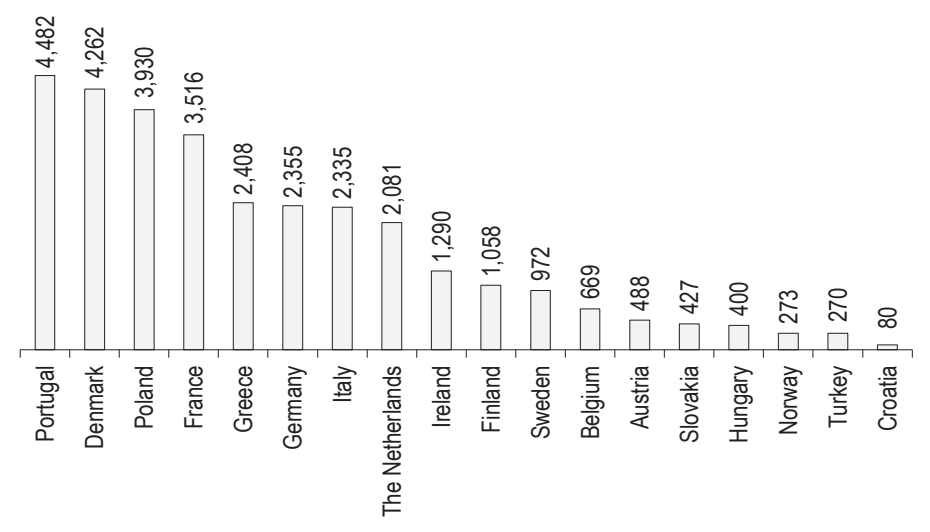

Figure 5. Geographical structure of EIB loans to PPP projects in total (EUR mln)

Source: by own based on PPPs (2018), pp. 1-21.

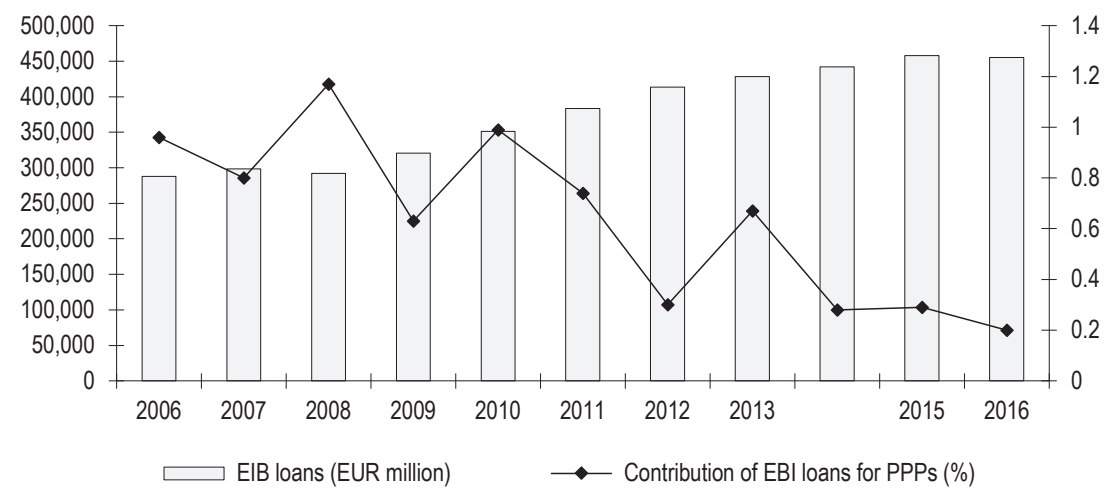

Figure 6. Loan portfolio of EIB in 2006-2016

Source: by own based on Financial (2007-2017), PPPs (2018), pp. 1-12.

A curve of a share loans for PPPs in Bank portfolio is still decreasing, which does no mean that ElB participation is becoming smaller and smaller. Real values of granted loans deny it. A curve shows only a internal structure of loan portfolio.

\section{Conclusions}

A research confirmed a leading role of European Investment Bank in providing financing to PPP projects in EU countries among other creditors. It should be underlined that:

1. An importance of EIB in PPP development in Europe is not possible to overestimate.

2. EIB acts as a lender for PPP projects and makes easier to find financial close.

3. EIB acts as a guarantor; EIB loan acts as a project surety. 
4. Additional, more and more important, support of EIB is developing activity in advising and training provided by law, finance, technical and technological EIB expert team.

\section{References}

Brzozowska, K. (2015). Znaczenie Europejkkiego Banku Inwestycyjnego w rozwoju partnerstwa publiczno-prywatnego w Europie. Research Papers of Wroctaw University of Economics, 412, 24-34.

European Investment Bank Financial Report (2006). Retrieved from: /www.eib.org/en/infocentre/publications/all/financial-report-2006. htm.

European Investment Bank Financial Report (2007). Retrieved from: www.eib.org/en/infocentre/publications/all/financial-report-2007. $\mathrm{htm}$.

European Investment Bank Financial Report (2008). Retrieved from: www.eib.org/en/infocentre/publications/all/financial-report-2008. htm.

European Investment Bank Financial Report (2009). Retrieved from: www.eib.org/en/infocentre/publications/all/financial-report-2009. $\mathrm{htm}$.

European Investment Bank Financial Report (2010). Retrieved from: www.eib.org/en/infocentre/publications/all/financial-report-2010. $\mathrm{htm}$.

European Investment Bank Financial Report (2011). Retrieved from: www.eib.org/en/infocentre/publications/all/financial-report-2011. $\mathrm{htm}$.

European Investment Bank Financial Report (2012). Retrieved from: www.eib.org/en/infocentre/publications/all/financial-report-2012. $\mathrm{htm}$.

European Investment Bank Financial Report (2013). Retrieved from: www.eib.org/en/infocentre/publications/all/financial-report-2013. htm.

European Investment Bank Financial Report (2014). Retrieved from: www.eib.org/en/infocentre/publications/all/financial-report-2014. $\mathrm{htm}$.

European Investment Bank Financial Report (2015), Retrieved from: www.eib.org/en/infocentre/publications/all/financial-report-2015. $\mathrm{htm}$.

European Investment Bank Financial Report (2016). Retrieved from: www.eib.org/en/infocentre/publications/all/financial-report-2016. $\mathrm{htm}$.

European Investment Bank Financial Report (2017). Retrieved from: www.eib.org/en/infocentre/publications/all/financial-report-2017. htm.

Bernaś, B. (ed.). (2006). Finanse międzynarodowe. Warszawa: Wydawnictwo Naukowe PWN.

Honohan, P. (1995). The Public Policy Role of the European Investment Bank within the EU. Journal of Common Market Studies, 3 , $315-330$.

Investment Report 2017/2018. (2018). European Investment Bank.

Market Update. Review of the European PPP Market in 2007-2016, EPEC.

PPPs financed by the European Investment Bank from 1990 to 2017 (2018). EPEC February.

The EIB's role in Public-Private Partnerships (PPPs) (2004). European Investment Bank.

Tuijnmann, A. (2009). The education Lending Policy of the European Investment Bank. European Journal of Education, 44 (1), 111-125. World Market Intelligence. European Investment Bank - Company Capsule, 4.03.2015.

Xianbai, J. (2017). Promoting regional development bank complementarity: challenges to Asia and lessons from Europe. Asia Europe Journal, 15, 261-281.

Cite this article aS: Brzozowska, K. (2018). European Investment Bank as a supporter of European PPPs. European Journal of Service Management, 3 (27/2), 49-56. DOI: 10.18276/ejsm.2018.27/2-06. 